\title{
New records of lichen species from western Mongolia
}

\section{Markus Hauck ${ }^{1}$, Tor Tønsberg ${ }^{2}$, Helmut Mayrhofer ${ }^{3}$, Uwe de Bruyn ${ }^{4}$, Ochirbat Enkh- tuya $^{5}$ \& Samjaa Javkhlan 5}

\author{
${ }^{1}$ Department of Plant Ecology, Albrecht von Haller Institute of Plant Sciences, Georg August University of Göttingen, \\ Untere Karspüle 2, D-37073 Göttingen, Germany. E-mail: mhauck@gwdg.de \\ ${ }^{2}$ Museum of Natural History, University of Bergen, Allégaten 41, Postboks 7800, N-5020 Bergen, Norway \\ ${ }^{3}$ Helmut Mayrhofer, Institute of Plant Sciences, Karl Franzens University of Graz, Holteigasse 6, A-8010 Graz, Austria \\ ${ }^{4}$ Von-Müller-Straße 30, D-26123 Oldenburg, Germany \\ ${ }^{5}$ Institute of Botany, Mongolian Academy of Sciences, Zhukov Street 7, Ulan Bator 51, Mongolia
}

\begin{abstract}
New records of lichens are compiled for the Mongolian Altai and the Khangai, western Mongolia. All records are from the forest-steppe. A total of 31 species are reported for the first time from the Mongolia Altai and another 18 species are new for the Khangai. Nineteen species, namely Arthonia mediella, Bacidia circumspecta, Blastenia furfuracea, Calicium viride, Caloplaca chlorina, Cyphelium karelicum, Lecanora allophana, L. boligera, L. cadubriae, L. subintricata, Lepraria ecorticata, L. rigidula, Leptogium subtile, Ochrolechia szatalaënsis, O. turneri, Placynthiella dasaea, Rinodina freyi, $R$. septentrionalis, and $R$. trevisanii, are new to Mongolia. The finding of Lepraria ecorticata from the Altai is the only one from Central Asia, whereas Rinodina freyi was not known from the whole of Asia so far.
\end{abstract}

\section{INTRODUCTION}

The lichen flora of Mongolia is better known than that of many other Central Asian countries or regions (Central Asia is treated here in a wide sense), like Kazakhstan (Wagner \& Spribille, 2005), Kyrgyzstan (Litterski, 2006), Tajikistan (Kudratov \& Mayrhofer, 2002), Xinjiang (Abbas et al., 2001) or Tibet (Wei, 1991). In Mongolia, compilations of the known species of lichenforming fungi have been published repeatedly (Golubkova, 1981; Cogt, 1995; Enkhtuya, 2007; Biazrov, 2010). Today, more than 1000 lichen species are known from Mongolia (Biazrov, 2010). Nevertheless, there are still substantial gaps of knowledge especially about the lichen flora of remote corners of the country, which are many. Early in the research on Mongolian biodiversity, the country was classified into 16 biogeographical regions (Fig. 1), a concept which is usually followed to describe the distribution of species within the country (Grubov, 1982, 2001). The present paper attempts to add new data on the lichen flora for two of these biogeographical regions, namely the Mongolian Altai and the Khangai, in western Mongolia. Especially the lichen flora of the Mongolian Altai is heavily under-researched, despite the biogeographical uniqueness of the Altai Mountains, due to the remoteness of the area. The lichen flora of the Khangai is better known due to the large longitudinal extension of this region, as its eastern parts in central Mongolia are easily accessible (Biazrov, 1989; Cogt, 1995).

\section{MATERIALS AND METHODS}

The studied regions in the Mongolian Altai and the Khangai belong to the forest-steppe region of Mongolia. These are high mountain areas, predominantly of siliceous rock, with the investigated sites having an elevation between 2100 and $2400 \mathrm{~m}$ a.s.1. The forest-steppe of western Mongolia is strongly dominated by Siberian larch (Larix sibirica Ledeb.). Forests are mostly found on north-facing mountain slopes, whereas south-facing slopes and most valleys are covered with grasslands. Above the treeline (ca. $2500 \mathrm{~m}$ a.s.1.) there is an alpine zone of grasslands and snowfields. The climate of western Mongolia is very continental with a subzero mean of annual temperature and low annual precipitation of ca. 200-300 $\mathrm{mm}$ in most forested area and less precipitation in dry steppes, semideserts and deserts, which were not covered by the present study. The forest-steppe of western Mongolia is the home of pastoral nomads, who settle in tent-like dwellings (gers) in the steppe. Their livestock is free-roaming and does not only graze the grasslands, but also the forests (Lkhagvadorj et al., 2013). The forests are highly fragmented. Especially the forest edges harbor a lichen veg- 


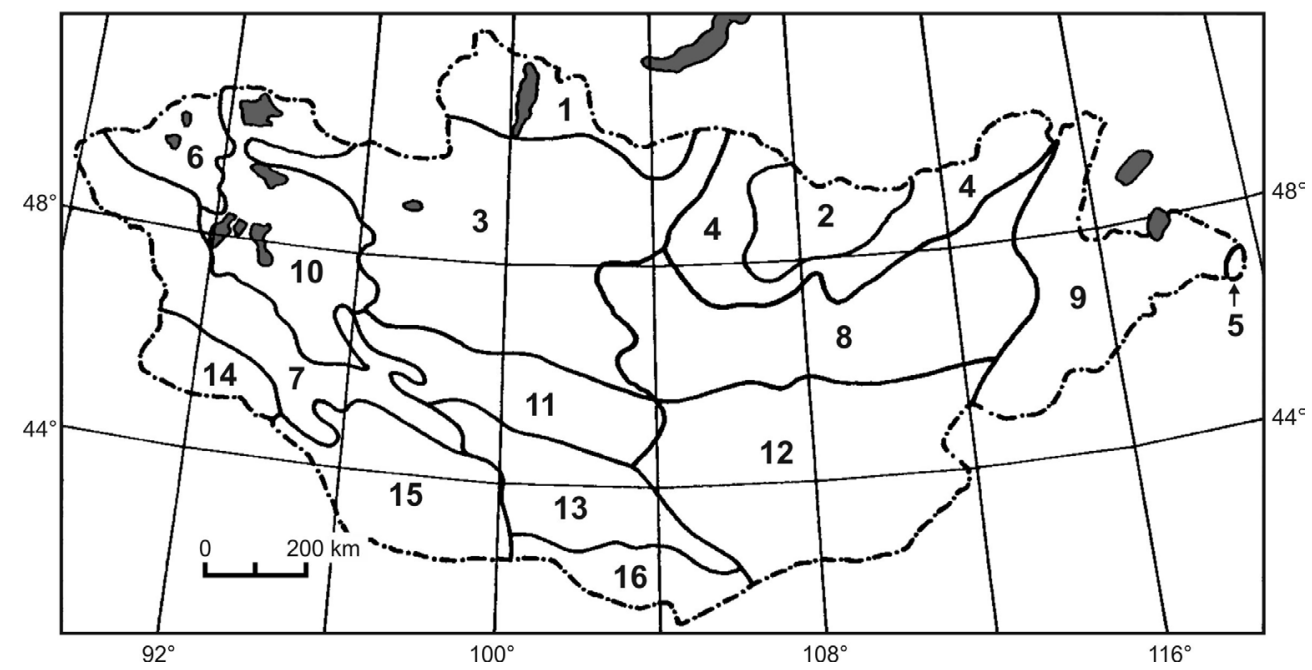

Fig. 1. Biogeographical regions in Mongolia according to Grubov (1982): (1) Khovsgol, (2) Khentei, (3) Khangai, (4) Mongolian Dauria, (5) Khingan, (6) Khovd, (7) Mongolian Altai, (8) Middle Khalkha, (9) East Mongolia, (10) Great Lakes Basin, (11) Valley of Lakes, (12) East Gobi, (13) Gobi-Altai, (14) Dzungarian Gobi, (15) Transaltai-Gobi, (16) Alashan-Gobi.

etation which is typical of nutrient and dust enriched sites. This is due to the enrichment of nutrients by the livestock and the deposition of dust from grasslands (Hauck et al., 2012; Hauck \& Lkhagvadorj, 2013). Accordingly, the epiphytic lichen vegetation of the Mongolian forest-steppe is a mixture of acidophytic and nitrophytic species (Biazrov, 1974; Hauck et al., 2012). Rock outcrops are mostly sun-exposed and harbor a rich flora of silicolous lichens; terricolous lichens are few in the steppe grasslands and become more frequent in alpine meadows and scree (Cogt, 1995).

Lichens were collected in the Mongolian Altai in 2010 by Markus Hauck, Samjaa Javkhlan and Ochirbat Enkhtuya, and in the Khangai in 2011 by Hauck, Uwe de Bruyn, Javkhlan and Enkhtuya. Since field work was conducted together, we did not note for every collection, who was involved in collecting the specific specimen, except for a few cases where the senior author wants to emphasize that the discovery of the relevant species merits to someone else. If nothing else is mentioned the specimens were identified by Hauck using standard microscopy techniques and spot tests. Thin-layer chromatography (TLC) in solvents A, B, C (Orange et al., 2001) was carried out by Tor Tønsberg where speci- fied. Herbarium specimens are deposited in the private herbarium of Markus Hauck.

The collecting sites are given as abbreviations A1 to A5 (Mongolian Altai) and K1 to K6 (Khangai) in the species list:

A1 to A5 - Bayan-Ulgii Province, vicinity of Lake Dayan Nuur;

A1 - 5 km SSE Lake Dayan Nuur, 2340 m a.s.1., $48^{\circ} 16^{\prime} \mathrm{N}, 88^{\circ} 56^{\prime} \mathrm{E}$, collected 27.07.2010;

A2 - $4 \mathrm{~km}$ S Lake Dayan Nuur, 2330-2400 $\mathrm{m}$ a.s.1., $48^{\circ} 15^{\prime} \mathrm{N}, 88^{\circ} 50^{\prime} \mathrm{E}$, collected 20.23.07.2010;

A3 - $1 \mathrm{~km}$ S Lake Dayan Nuur, 2320 m a.s.1., $48^{\circ} 16^{\prime} \mathrm{N}, 88^{\circ} 52^{\prime} \mathrm{E}$, collected 17.07.2010;

A4 - $1 \mathrm{~km}$ SSE Lake Dayan Nuur, 2370 m a.s.1., $48^{\circ} 15^{\prime} \mathrm{N}, 88^{\circ} 54^{\prime} \mathrm{E}$, collected 12.07.2010;

A5 - $5 \mathrm{~km}$ SSE Lake Dayan Nuur, $2310 \mathrm{~m}$ a.s.1., $48^{\circ} 15^{\prime} \mathrm{N}, 88^{\circ} 56^{\prime} \mathrm{E}$, collected $27.07-$ 02.08.2010.

K1 to K6 - Zavkhan Province, Shireegiin Gol, ca. $25 \mathrm{~km}$ SW Mt. Otgontenger;

$\mathrm{K} 1-2195-2220 \mathrm{~m}$ a.s.1., $47^{\circ} 31^{\prime} \mathrm{N}, 97^{\circ} 11^{\prime} \mathrm{E}$, collected 10.08.2011;

$\mathrm{K} 2-2125-2170 \mathrm{~m}$ a.s.1., $47^{\circ} 30^{\prime} \mathrm{N}, 9^{\circ} 6^{\prime} \mathrm{E}$, collected 11.08.2011;

K3 - 2145-2175 $\mathrm{m}$ a.s.1., $47^{\circ} 29^{\prime} \mathrm{N}, 9^{\circ} 4^{\prime} \mathrm{E}$, collected 12.08.2011;

$\mathrm{K} 4-2215-2240 \mathrm{~m}$ a.s.1., $47^{\circ} 30^{\prime} \mathrm{N}, 9^{\circ} 8^{\prime} \mathrm{E}$, collected 08.-09.08.2011; 
$\mathrm{K} 5$ - $2300 \mathrm{~m}$ a.s.1., $47^{\circ} 30^{\prime} \mathrm{N}, 97^{\circ} 14^{\prime} \mathrm{E}$, collected 10.08.2011;

K6 - $2215 \mathrm{~m}$ a.s.1., $47^{\circ} 30^{\prime} \mathrm{N}, 97^{\circ} 9^{\prime} \mathrm{E}$, collected 09.08.2011.

If not stated otherwise, the substratum was bark or wood of Larix sibirica.

Diagnostic characters are provided for all species, which are new to Mongolia. All descriptions refer to the cited and sometimes additional specimens from the study area, but sometimes to more than the cited specimens, as specimen citation was limited to one selected sample per study area (Mongolian Altai, Khangai Mountains). Some lichens in this paper are already mentioned in Hauck et al. (2012), which deals mainly with ecological aspects and land-use issues. If the taxa are new to Mongolia or the Mongolian Altai, they are included in the present paper despite earlier publication in the tables of the paper mentioned above. Nomenclature of lichen species is based on Urbanavichus (2010), except for the Teloschistaceae (Arup et al., 2013).

\section{THE SPECIES}

Arthonia apatetica (A. Massal.) Th. Fr. - A1. New to Mongolian Altai.

The species was repeatedly found on trunk bases of larch trees, preferentially on slightly nutrientenriched bark at the forest edge to steppe at places that are influenced by livestock grazing, but sometimes also in the less heavily grazed forest interior. Usually $A$. apatetica grows on trunk bases with very low competition by other epiphytes; sometimes the species was associated with Lecanora albellula (Nyl.) Th. Fr. (=L. piniperda Körb.). The species was reported by Hauck \& Javkhlan (2006) from shrubs of Spiraea aquilegifolia from the Khentei and is also known from southern Siberia (Urbanavichus, 2010).

ARthonia mediella Nyl. - A2. New to Mongolia. The specimens are characterized by triseptate ascospores $(10-18 \times 4 \mu \mathrm{m})$, the dark brown epihymenium (paraphyses with pigmented caps), the hyaline hymenium $(35-40 \mu \mathrm{m})$, the red brown hypothecium and the chlorococcoid photobiont. A. mediella was found, for example, together with Calicium viride Pers. on the bark of Larix sibirica at the trunk base. In contrast to most other species of the genus which prefer warm regions, A. mediella is a circumpolar, boreal-montane to cold-temperate species and occurs, among others, in Siberia and the Russian Far East (Urbanavichus, 2010) and eastern Kazakhstan (Hauck et al., 2013).

BACIDIA CIRCUmspecta (Nyl. ex Vain.) Malme - A2. New to Mongolia.

The specimen has black, marginate apothecia (up to $1 \mathrm{~mm}$ ) with black green, $\mathrm{K}$ - epihymenium, hyaline, $\mathrm{K}$ - hymenium and hypothecium, a light red brown, $\mathrm{K}+$ purple exciple and 4-6-celled ascospores of $18-28 \times 2-2.5 \mu \mathrm{m}$. The species is apparently rare in Mongolia. It was found on the side surface of a coarse root of an old larch tree at the forest edge very close to the ground floor; in this microhabitat, the lichen was protected from the high solar irradiation and the high evaporative demand in the forest-steppe ecotone by the closeness to the soil surface and the dense herb layer. B. circumspecta is widely distributed in the northern hemisphere; its known distribution in neighboring areas includes southern and western Siberia and the Russian Far East (Urbanavichus, 2010).

Biatora Chrysantha (Zahlbr.) Printzen - A2, K1. New to Mongolian Altai and Khangai.

$B$. chrysantha was repeatedly found on trunk bases and deadwood of larch. Previous records from Mongolia are from Lake Khovsgol (Palka \& Śliwa, 2006) and the Khentei (Hauck \& Javkhlan, 2006).

Blastenia furfuracea (H. Magn.) Arup, Søchting \& Frödén [= Caloplaca $f$. H. Magn.] - A2. New to Mongolia.

The species consists of a thallus with dark grey to blackish, granular (never branched and never orange) isidia and red-orange apothecia. $B$. furfuracea is widespread in larch forests of the Mongolian Altai and occurs on both the bark of living trees (at the trunk base) and decorticated lying tree trunks. The species is listed in the checklist for Kazakhstan by Wagner $\&$ Spribille (2005), which was, however, published before the revision of the $B$. furfuracea/herbidella group by Arup \& Åkelius (2009). However, $B$. furfuracea has also recently been recorded from Larix sibirica from the Saur Mountains, eastern Kazakhstan by Hauck et al. (2013). B. furfuracea is not known from Russia (Urbanavichus, 
2010), but from Europe (Scandinavia, Alps) and western North America (Wetmore, 2004; Arup \& Åkelius, 2009). The occurrence of $B$. furfuracea in the Altai and Saur Mountains agrees well with the assessment of Arup \& Åkelius (2009) that the species would prefer cold winter climates at high altitudes. The strong preference for decorticated wood as found in Europe (Arup \& Åkelius, 2009) is neither supported by the findings from North America (Wetmore, 2004) nor the Altai. The similar $B$. herbidella (Hue) Servit has recently been reported from the Russian Altai (Davydov \& Printzen, 2012).

Buellia ERUbescens Arnold - K2. New to Khangai. $B$. erubescens was found on the bark of larch trees. The species was already known from other provinces of Mongolia, including Khentei, Mongolian Dauria and Khovd (Cogt, 1995).

Buellia GRiseovirens (Turner \& Borrer ex Sm.) Almb. - A2. New to Mongolian Altai.

The species was repeatedly found on decorticated coarse deadwood in the forest interior. $B$. griseovirens is already known from Mongolia from the Lake Khovsgol area (Palka \& Śliwa, 2004) and the Khentei (Hauck \& Javkhlan, 2006).

CAlicium viride Pers. - A2. New to Mongolia. The species is easily recognized by its yellowish green thallus with stalked apothecia, brown, epruinose exciple and black mazaedium. C. viride is a rather common species in Larix sibirica forests of the Mongolian Altai. It prefers rainsheltered parts at the trunk base. The species is known from all forested parts of Siberia and the Russian Far East (Urbanavichus, 2010) and Kazakhstan (Wagner \& Spribille, 2005).

Caloplaca Chlorina (Flot.) Sandst. - K3. New to Mongolia.

The species is characterized by Caloplaca cerinalike apothecia, which are formed on a dark gray thallus which is partly blastidiate to sorediate, but also has some areolae which are not completely dissolved into soredia. C. chlorina was found on nutrient-enriched trunk bases at the forest edge to the steppe. The species is widely distributed in the northern hemisphere (Šoun et al., 2011) and occurs, among others, in southern Siberia (Urbanavichus, 2010) and eastern Kazakhstan (Hauck et al., 2013).
Candelariella Reflexa (Nyl.) Lettau - K4. New to Khangai.

The species is common on moderately nutrientenriched bark at the trunk base of larch trees, especially at the forest edge to the steppe, but also in the forest interior. It is often associated with Xanthoria s.1. and Physcia dubia (Hoffm.) Lettau and $P$. adscendens $\mathrm{H}$. Olivier. The species is also known from the Mongolian Altai where it is similarly common as in the western Khangai (Cogt, 1995, Hauck et al., 2012).

Cladonia bacilliformis (Nyl.) Glück - A3. New to Mongolian Altai.

The species was found at the trunk base of a larch tree. C. bacilliformis was already known from the Khentei and the Khangai Mountains (Biazrov, 2010).

Cyphelium Karelicum (Vain.) Räsänen - A1. New to Mongolia.

This lichen has a mostly thin and inconspicuous grayish thallus with sessile apothecia and verrucose (not striated), 2-celled brown ascospores, which are constricted at the septum. C. karelicum was repeatedly found on trunk bases of Larix sibirica in the Mongolian Altai. In Asia, this circumboreal species is known from eastern Siberia, the Siberian Arctic and the northern Russian Far East (Urbanavichus, 2010).

LeCANia NAEgeli (Hepp) Diederich \& Van den Boom - A4. New to Mongolian Altai.

L. naegelii was found in the interior of a grazed larch forest at the base of a tree trunk and was associated with Arthonia apatetica. Cogt (1995) published a record of $L$. naegelii from Salix from the Khangai Mountains.

Lecanora allophana (Ach.) Nyl. - A5. New to Mongolia.

The material has red-brown apothecia (up to 2 $\mathrm{mm}$ ) with flexuose, crenulate, inward-curved thalline margin and a constricted base on whitish gray, $\mathrm{K}+$ yellow (atranorin) thallus. The exciple has small crystals, which occur in both the medulla and the cortex. The epihymenium is red-brown and lacks granules; the spore size is $18-20 \times 7.5-12 \mu \mathrm{m}$. L. allophana is apparently rare in Mongolia. It was found once in the Mongolian Altai on the roots of an old larch tree close to the soil surface in an open woodland close to the steppe at a place which was exposed to 
moderate nutrient input due to livestock grazing. The species was associated with Melanohalea elegantula (Zahlbr.) O. Blanco et al., Rinodina septentrionalis Malme, Caloplaca cerina (Ehrh. ex Hedw.) Th. Fr., and Lecanora hagenii (Ach.) Ach. L. allophana is widely distributed in both hemispheres and is also known from Siberia, the Russian Far East (Urbanavichus, 2010), Kazakhstan (Wagner \& Spribille, 2005) and China (Wei, 1991).

LeCANora boligera (Norman ex Th. Fr.) Hedl. A2. New to Mongolia.

The lichen has globose to subglobose, one-celled ascospores of 5-7 $\times 5 \mu \mathrm{m}$, which are formed in apothecia (up to $0.4 \mathrm{~mm}$ ) with a brown to blackish brown disc and usually brighter (brown) margin. The thallus is verrucose to areolate, brownish gray to off-white, $\mathrm{K}+$ yellow, UV+ white. L. boligera was found several times, but much rarer than the similar L. cadubriae in the Mongolian Altai, where it occurred at trunk bases of larch trees in the forest interior. Like that species, L. boligera has a circumboreal distribution. In the Asian part of Russia, it is recorded from southern Siberia, the Siberian Arctic and the Russian Far East (Urbanavichus, 2010).

LeCANora CAdubriae (A. Massal.) Hed1. - A2, K2. New to Mongolia.

L. cadubriae is characterized by the light gray, $\mathrm{K}+$ yellow, then red thallus (norstictic acid) with black semi-immersed pycnidia and brown to reddish brown apothecia with narrowly ellipsoid, one-celled ascospores of 8-13 $\times 3 \mu \mathrm{m}$, a brown epihymenium and hyaline hymenium and hypothecium. The species grows on larch trees, preferably at the trunk base. It is quite common in the Mongolian Altai and apparently rare in the western Khangai. L. cadubriae is a circumboreal species, which is also known from southern, western and eastern Siberia (Urbanavichus, 2010) and eastern Kazakhstan (Hauck et al., 2013).

Lecanora Chlarotera Nyl. - A2. New to Mongolian Altai.

On bark of Larix sibirica at trunk base, associated with Amandinea punctata (Hoffm.) Coppins \& Scheid., Candelariella reflexa and Polycauliona candelaria (L.) Frödén, Arup \& Søchting (= Xanthoria c., Massjukiella c.) in forest occasionally grazed by livestock. The species was previously known from Mongolia from the Khentei (Huneck et al., 1984).

LECANORA Dispersa (Pers.) Sommerf. - K5. New to Khangai.

The species grew on decorticated wood of a trunk base of a larch tree at the forest edge to the steppe. It was associated with Lecanora hagenii and Candelariella aurella (Hoffm.) Zahlbr. In contrast to L. hagenii, L. dispersa is a rare species in Mongolia, which was, so far, only known from a single collection from Middle Khalkha (Cogt, 1995).

LeCANORA MUGHicola Nyl. - A2. New to Mongolian Altai.

On decorticated, sun-exposed wood in the subalpine zone of Larix sibirica forest. Palka \& Śliwa (2004) published L. mughicola from the Lake Khovsgol area.

LeCANora pulicaris (Pers.) Ach. - A2. New to Mongolian Altai.

The species is widespread in the Mongolian Altai on the bark of Siberian larch, but was always found with few small thalli. It was previously recorded from the phytogeographical districts Khovd, Khovsgol and Khangai (Cogt, 1995; Palka \& Śliwa, 2006).

LeCAnora subintricata (Nyl.) Th. Fr. - A4, K4. New to Monglia.

L. subintricata has to be carefully separated from $L$. albellula ( $=$ L. piniperda), which is (like L. subintricata) a widespread epiphyte in Mongolian larch forests. Since $L$. subintricata is relatively common in western Mongolia, it has probably been confused with $L$. albellula in the past. L. subintricata has more regularly formed and more isolated apothecia and a less distinct thallus than $L$. albellula. The ascospores (6-12 $\times 3-4 \mu \mathrm{m})$ tend to be smaller and the hymenium $(25-45 \mu \mathrm{m})$ is shallower than in L. albellula, though there is a considerable overlap especially with spores sizes. The two species also differ in secondary chemistry (van den Boom \& Brand, 2008); the main lichen substance of $L$. subintricata is usnic acid, whereas the Eurasian populations of $L$. albellula produces isousnic acid as major substance and usnic acid only in trace amounts. If found, the curved leptoconidia of $10-15(-18) \times$ ca. $1 \mu \mathrm{m}$ are a very characteristic feature of $L$. albellula that lacks $L$. subintricata. 
The latter tends to prefer the middle stem of larch trunks, whereas L. albellula is more often found at the trunk base. Both species sometimes co-occur on the same tree. L. subintricata is a circumboreal species, which is also known from the forested parts of Siberia and the Russian Far East (Urbanavichus, 2010; Davydov \& Printzen, 2012) as well as Kazakhstan (Wagner $\&$ Spribille, 2005).

LECIDEA HYPNORUM Libert - K2, leg. U. de Bruyn. The specimen has dark reddish brown apothecia (1.3 $\mathrm{mm}$ in diam.) with thin persistent margin. The ascospores are hyaline, broadly ellipsoid, 1-2-celled, slightly constricted at the septum and have a size of 10-13 $55 \mu \mathrm{m}$. The epihymenium is yellowish brown, the hymenium $(40 \mu \mathrm{m})$ is hyaline, and the hypothecium is brownish to hyaline. The width of spores and the dark, marginate apothecia separate the species from the similar L. sanguineoatra, which was recently reported from the Russian Altai (Davydov \& Printzen, 2012). The specimen from the Khangai was collected from the base of a larch trunk in the interior of a larch forest, where it grew between corticolous mosses. It is not clear from the literature whether L. hypnorum has been previously found in Mongolia or not. Cogt (1995) and Biazrov (2010) synonymized L. hypnorum with Mycobilimbia tetramera (De Not.) Vitik. et al., but these taxa are not even congeneric. The specimens from the Khangai and the Khentei, which are the basis for these records, could not be checked for the present study. L. hypnorum is widely distributed in Siberia and the Russian Far East (Urbanavichus, 2010).

LEPRARIA ECORTICATA (J.R. Laundon) Kukwa -A5, on siliceous rock, det. T. Tønsberg (TLC: usnic acid, zeorin). New to Mongolia and Central Asia. The specimen is a yellowish green leprose crust. The chemically identical L. leuckertiana (Zedda) L. Saag has a white medulla, which lacks in the specimen from Mongolia. L. ecorticata was found on vertical surfaces of a small siliceous rock in a larch forest of the Mongolian Altai. The nearest record of $L$. ecorticata is from Xiamen, south-eastern China (Kukwa, 2006).

LEPRARIA RIGIDUla (B. de Lesd.) Tønsberg -A1, on siliceous rock, det. T. Tønsberg (TLC: atranorin, nephrosteranic acid). New to Mongolia.

L. rigidula is characterized by the production of the fatty acid nephrosteranic acid in addition to the depside atranorin and the bluish to whitish gray soredia with projecting hyphae. The nearest records of $L$. rigidula are from Kazakhstan (Hauck et al., 2013), Armenia (Harutyunyan et al., 2011), Iran (Moniri \& Kukwa, 2009), eastern Anatolia (Kümmerling et al., 1995), the southern Ural Mountains and the Russian Caucasus (Urbanavichus, 2010).

Leptogium subtile (Schrad.) Torss. - K3, leg. U. de Bruyn. New to Mongolia.

The specimen has a small (8 $\mathrm{mm}$ in diam.), rosette-like thallus with smooth lobes, which are paraplectenchymatous throughout, and numerous apothecia of $0.2-0.6 \mathrm{~mm}$ in diam. The spores are muriform and have a size of (17-)20-27(-30) × 10-15 $\mu \mathrm{m}$. The lichen grew directly on the bark of a mossy trunk base of a larch tree and was associated with Caloplaca cerina, Lecanora hagenii and Physcia stellaris (L.) Nyl. Leptogium subtile is widely distributed in the northern hemisphere and is known in neighbouring areas from southern, western and eastern Siberia, and the Russian Far East (Urbanavichus, 2010).

OCHROLECHIA ANDROGYNA (Hoffm.) Arnold s.lat. A3. New to Mongolian Altai.

The species was found on bark and decorticated wood of larch, and was associated with Blastenia furfuracea, Calicium viride, Hypocenomyce scalaris (Ach. ex Lilj.) M. Choisy, Hypogymnia bitteri (Lynge) Ahti, Lecanora varia (Hoffm.) Ach., Parmelia sulcata Taylor, Parmeliopsis ambigua (Wulfen) Nyl., and Vulpicida pinastri (Scop.) J.-E. Mattsson \& M.J. Lai. Ochrolechia androgyna was already known from the Khangai, where it was found on soil (Cogt, 1995). Sedelnikova (1990) published $O$. androgyna from the Russian Altai.

Ochrolechia szatalaËnsis Verseghy - A2, det. T. Tønsberg (TLC: variolaric acid and unknown substances). New to Mongolia.

The specimen is characterized by the content of variolaric acid, which causes the $\mathrm{C}+$ yellow reaction of the apothecial disc. Cortex of the amphithecium is hyaline and ca. $25 \mu \mathrm{m}$ wide laterally, but is opaque and $150-200 \mu \mathrm{m}$ wide at the base. The thallus morphology is variable from very thin and smooth to slightly rugulose on smooth surfaces and to rugose to verrucose at places where the lichen overgrows plant debris, 
which was deposited on the wood surfaces. This variability in the thallus morphology disagrees with the characterization by Brodo (1991), but is in accordance with the descriptions by Verseghy (1962) and especially Kukwa $(2009,2011)$. O. szatalaënsis is very similar to the terricolous O. upsaliensis (L.) A. Massal., but differs by a good developed opaque cortex of the apothecial thalline margine which is absent in the latter (Kukwa, 2009, 2011). The species was found once on a rotten, decorticated trunk of Larix sibirica (diam. $35 \mathrm{~cm}$ ) lying on the ground in larch forest, associated with Blastenia furfuracea and Lecidella euphorea (Flörke) Hertel. Ochrolechia szatalaënsis is obviously a threatened species in Mongolia, since deadwood is systematically removed from the forests for fuel (Lkhagvadorj et al., 2013). O. szatalaënsis is known from both hemispheres and occurs in eastern Kazakhstan (Hauck et al., 2013), the Russian Far East, the Caucasus (Urbanavichus, 2010) and Turkey (Kukwa, 2011).

OCHROLECHIA TURNERI (Sm.) Hasselrot - A2, det. T. Tønsberg (TLC: variolaric acid). New to Mongolia. The species with its whitish gray thallus with mostly discrete soralia is characterized by its $\mathrm{C}+/ \mathrm{KC}+$ yellow reaction. It lacks the fatty acid lichenesterinic acid, which is characteristic of the similar O. microstictoides Räsänen (Kukwa, 2008). O. turneri was repeatedly found on the trunk bases of larch trees in the Mongolian Altai. The records of $O$. microstictoides in Hauck et al. (2012) (det. M. Hauck) belong to O. turneri. The Mongolian records of $O$. turneri represent together with recent collections from eastern Kazakhstan (Hauck et al., 2013) the only records of this species from Central Asia. The species is known from southern Siberia, including the Russian Altai, the southern Russian Far East (Sedelnikova, 1990, Urbanavichus, 2010) and Iran (Kukwa, 2011).

Peltigera didactyla (With.) J.R. Laundon - A2. New to Mongolian Altai.

The species grew some $\mathrm{cm}$ above the soil surface on coarse roots of an old larch tree at the forest edge to the steppe; it was associated with Leptogium tenuissimum (Hoffm.) Körb. and Peltigera rufescens (Weiss) Humb. P. didactyla has earlier been reported from several districts of Mongolia, including Khovsgol, Khentei, Khangai, Mongolian Dauria, Khovd, Middle Khalkha, and Khingan (Cogt, 1995).
Physcia Adscendens H. Olivier - K3. New to Khangai.

The species is widespread in the western Khangai on nutrient-enriched trunk bases of larch trees at forest edge to the steppe, but usually occurs with few thalli per tree only. P. adscendens was already known from the Mongolian Altai and the Khentei (Hauck \& Javkhlan, 2006).

Physciella Chloantha (Ach.) Essl. - A2, K6. New to Mongolian Altai and Khangai.

$P$. chloantha was found on moderately nutrientenriched trunk bases of larch trees at the forest edge to the steppe. The species has earlier been reported from the Khentei (Hauck \& Javkhlan, 2006). In Mongolia, the species was apparently overlooked a long time; it seems to be a widespread epiphyte of slightly acidic bark in Central Asia.

Physconia hokkaidensis Kashiw. - A2. New to Mongolian Altai.

The species was found on the trunk bases of larch trees, especially on coarse roots at the forest edge to the steppe close to the soil surface. It was associated with, for example, Caloplaca cerina, Candelariella reflexa, Lecanora hagenii, Physcia dubia, and Physciella chloantha. Physconia hokkaidensis was already reported from Mongolia from the Khangai and Middle Khalkha (Huneck et al., 1987). P. hokkaidensis is an East Asian species which is otherwise known from Japan (Kashiwadani, 1975), China (Chen \& Hu, 2003) and southern and eastern Siberian and the southern Russian Far East (Urbanavichus \& Urbanavichene, 2005).

Placynthiella dasaea (Stirt.) Tønsberg - A5, K3. New to Mongolia.

On the bark of at the trunk base of larch trees or on decorticated deadwood (with Xylographa parallela (Ach.) Fr.). The species has long been neglected and is much overlooked, though it is easily recognized by the thallus consisting of clusters (consoredia) of brown soredia at the outer face of the consoredia and greenish soredia in the interior of the consoredia as well as the $\mathrm{C}+$ red reaction due to the production of gyrophoric acid (Tønsberg, 1992). From the Asian part of Russia, P. dasaea is known from western and southern Siberia and the Russian Far East (Urbanavichus, 2010). 
Placynthiella icmalea (Ach.) Coppins \& P. James - K3. New to Khangai.

The cited specimen is fertile. The species was found at the base of larch trees in the forest interior. Previous reports of $P$. icmalea from Mongolia are from Lake Khosgol (Palka \& Śliwa, 2004) and the Khentei (Hauck \& Javkhlan, 2006).

Placynthiella uliginosa (Schrad.) Coppins \& P. James - K1. New to Khangai.

The species was found on the trunk base of a larch tree at the forest edge to the steppe. $P$. ulginosa was already known from Mongolia (Khovsgol, Khentei, Mongolian Altai) (Schubert \& Klement, 1971; Palka \& Śliwa, 2004; Hauck \& Javkhlan, 2006).

RinOdinA fREYI H. Magn. - K5, det. H. Mayrhofer. New to Asia.

The thallus is dark grayish, rimose to areolate with contiguous areoles and the apothecia are broadly attached becoming contiguous. The ascospores have thick apical walls (Physcia-type). $R$. freyi was found on the decorticated part of a trunk base at the forest edge. The species is widely distributed in the temperate and southern boreal forests of North America; in Europe it is known from Scandinavia and the Alps (Ropin \& Mayrhofer, 1993; Sheard, 2010) and the Tatra mountain range (Ropin \& Mayrhofer, 1993).

Rinodina SEPTENTRIONALIS Malme - A2, det. H. Mayrhofer; K2, det. H. Mayrhofer. New to Mongolia.

The species is characterized by the combination of a thin copper-brown thallus with distinct areoles, narrowly attached scattered apothecia and Physcia-type ascospores. $R$. septentrionalis was found at forest edges on trunk bases of larch trees, often in very close proximity to the ground. It was already known from Siberia and the Russian Far East (Sheard, 2010; Urbanavichus, 2010). The species has a wide distribution in the arctic and boreal zones (Sheard, 2010).

Rinodina tReVisani (Hepp) Körb. - A1, det. H. Mayrhofer; K2, det. H. Mayrhofer. New to Mongolia.

The species is apparently widespread in western Mongolia on trunk bases and twigs and seems to prefer horizontal surfaces. In the Khangai, $R$. trevisanii was partly associated with $R$. cinereovirens (Vain.) Vain. It is a circumboreal species (Mayrhofer \& Sheard, 2007), which is also known from southern and eastern Siberia (Mayrhofer \& Sheard, 2007; Urbanavichus, 2010), eastern Kazakhstan (Hauck et al., 2013), Georgia and Turkey (Mayrhofer \& Sheard, 2007). The material assigned to $R$. sophodes (Ach.) A. Massal. (det. M. Hauck) in Hauck et al. (2012) refers to $R$. trevisanii.

Trapeliopsis flexuosa (Fr.) Coppins \& P. James - A1, det. T. Tønsberg [TLC: gyrophoric acid (major), lecanoric acid (trace)]. K4. New to Mongolian Altai and Khangai.

T. flexuosa grows on trunk bases of Siberian larch; T. granulosa (Hoffm.) Lumbsch co-occurred in the same forest stands. So far, $T$. flexuosa was known from Lake Khovsgol and Mongolian Dauria (Palka \& Śliwa, 2004).

Trapeliopsis GRanulosa (Hoffm.) Lumbsch - A2, det. T. Tønsberg [TLC: gyrophoric acid (major), lecanoric acid (trace)]. New to Mongolian Altai. The species was found on trunk bases and lying deadwood of Larix sibirica. T. granulosa was already known from Mongolia from the Khangai (Biazrov, 1989) and the Khentei (Hauck \& Javkhlan, 2006).

Xanthomendoza ulophyllodes (Räsänen) Søchting, Kärnefelt \& S.Y. Kondr. [= Oxneria $u$. (Räsänen) S.Y. Kondr. \& Kärnefelt, Xanthoria u. Räsänen] - K3. New to Khangai.

The species was repeatedly found on trunk bases of larch trees at the forest edge to the steppe. $X$. ulophyllodes was already known from northern Mongolia from the Khentei (Hauck \& Javkhlan, 2006).

Xylographa Parallela (Ach.) Fr. - A2. New to Mongolian Altai.

$X$. parallela grew on decorticated, downed trunks of Larix sibirica. The species was previously reported from Mongolia from larch forests of the Khentei and the Khangai Mountains (Cogt, 1995).

\section{ACKNOWLEDGMENTS}

The study was supported by a grant of the Volkswagen Foundation for the project "Forest regeneration and biodiversity at the forest-steppe border of the Altai and Khangai Mountains under contrasting developments of livestock numbers in Kazakhstan and Mongolia". We are thankful to the Altai Tavan Bogd National Park 
for permissions for field work. Bernd Raufeisen (Göttingen) prepared the maps of Mongolia. Lev Biazrov (Moscow), Walter Obermayer (Graz) and Tiina Randlane (Tartu) are thanked for their comments on the manuscript.

\section{REFERENCES}

Abbas, A., Mijit, A., Tumur, A. \& Jinong, W. 2001. A checklist of the lichens of Xinjiang, China. Harvard Papers in Botany 5: 359-370.

Arup, U. \& Åkelius, E. 2009. A taxonomic revision of Caloplaca herbidella and C. furfuracea. Lichenologist 41: 465-480. http://dx.doi.org/10.1017/ S0024282909008780

Arup, U., Søchting, U. \& Frödén, P. 2013. A new taxonomy of the family Teloschistaceae. Nordic Journal of Botany 31: 16-83.

Biazrov, L. G. 1974. Lichen synusiae in herb larch forests (Khangai Mountain Ridge, Mongolia). Botanicheskii Zhurnal 59: 1425-1438.

Biazrov, L. G. 1989. Lishayniki [Lichens]. Biologicheskie Resursy i Prirodnye Usloviia Mongolii 33: 17-73 (in Russian).

Biazrov, L. G. 2010. Checklist of the Mongolian lichens. Version 7 http: / / www.sevin.ru/laboratories_eng/ biazrov_mong.html.

Brodo, I. M. 1991. Studies in the lichen genus Ochrolechia. 2. Corticolous species of North America. Canadian Journal of Botany 69: 733-772. http:/ / dx.doi.org/10.1139/b91-099

Chen, J.-B. \& Hu, G.-R. 2003. The lichen family Physciaceae (Ascomycota) in China V. The genus Physconia. Mycotaxon 86: 185-194

Cogt, U. 1995. Die Flechten der Mongolei. Willdenowia 25: 289-397.

Davydov, E. A. \& Printzen, C. 2012. Rare and noteworthy boreal lichens from the Altai Mountains (South Siberia, Russia). Bryologist 115: 61-73. http://dx.doi.org/10.1639/0007-2745.115.1.61

Enkhtuya, O. 2007. Mongol orny khagiin burtgel bichig [Checklist of lichens of Mongolia]. Bembi San, Ulan Bator (in Mongolian).

Golubkova, N. S. 1981. Konspekt flori lishaynikov Mongol'skoy Narodnoy Respubliki [Catalogue of the lichen flora of the Mongolian People's Republic]. Biologicheskie Resursy i Prirodnye Usloviia Mongolii 16: 1-200 (in Russian).

Grubov, V. I. 1982. Opredelitel sosudistykh rastenij Mongolii (s atlasom) [Key to the vascular plants of Mongolia (with an Atlas)]. Nauka, Leningrad (in Russian).

Grubov, V. I. 2001. Key to the vascular plants of Mongolia (with an atlas). Volumes 1-2. Science Publishers, Enfield.

Harutyunyan, S., Wiesmair, B. \& Mayrhofer, H. 2011. Catalogue of the lichenized fungi in Armenia. Herzogia 24: 265-296.
Hauck, M. \& Javkhlan, S. 2006. Additions to the lichen flora of Mongolia: records from Khentei and Khangai. Willdenowia 36: 895-912. http://dx.doi. org/10.3372/wi.36.36221

Hauck, M. \& Lkhagvadorj, D. 2013. Epiphytic lichens as indicators of grazing pressure in the Mongolian forest-steppe. Ecological Indicator 32: 82-88. http: / dx.doi.org/10.1016/j.ecolind.2013.03.002

Hauck, M., Javkhlan, S., Lkhagvadorj, D., Bayartogtokh, B. Dulamsuren, Ch. \& Leuschner, C. 2012. Edge and land-use effects on epiphytic lichen diversity in the forest-steppe ecotone of the Mongolian Altai. Flora 207: 450-458. http://dx.doi. org/10.1016/j.flora.2012.03.008

Hauck, M., Tønsberg, T., Mayrhofer, H. \& Breuss, O. 2013. Lichen-forming and lichenicolous fungi new to Kazakhstan. Herzogia 26, in press.

Huneck, S., Poelt, J., Ahti, T., Vitikainen, O. \& Cogt, U. 1984. Zur Verbreitung und Chemie von Flechten der Mongolischen Volksrepublik (Ergebnisse der Mongolisch-Deutschen Biologischen Expeditionen seit 1962, Nr. 128). Erforschung der Biologischen Ressourcen der Mongolischen Volksrepublik 4: 51-62.

Huneck, S., Poelt, J., Ahti, T., Vitikainen, O. \& Cogt, U. 1987. Zur Verbreitung und Chemie von Flechten der Mongolischen Volksrepublik. II. Ergebnisse der Mongolisch-Deutschen Botanischen Expeditionen seit 1962 Nr. 177. Nova Hedwigia 44: 189-213.

Kashiwadani, H. 1975. The genera Physcia, Physconia and Dirinaria (lichens) of Japan. Ginkgoana [Tokyo] 3: 1-77.

Kudratov, I. \& Mayrhofer, M. 2002. Catalogue of the lichenized and lichenicolous fungi of Tajikistan. Herzogia 15: 91-128.

Kukwa, M. 2006. Notes on taxonomy and distribution of the lichen species Lepraria ecorticata comb. nov. Mycotaxon 97: 63-66.

Kukwa, M. 2008. The lichen genus Ochrolechia in Poland II. Sorediate taxa with variolaric acid. Herzogia 21: 5-24.

Kukwa, M. 2009. The lichen genus Ochrolechia in Poland III with a key and notes on some taxa. Herzogia 22: 43-66.

Kukwa, M. 2011. The lichen genus Ochrolechia in Europe. Fundacja Rozwoju Uniwersytetu Gdańskiego, Gdańsk.

Kümmerling, H. Leuckert, C., \& Wirth, V. 1995. Chemische Flechtenanalysen X. Lepraria rigidula (B. de Lesd.) Tønsberg. Nova Hedwigia 60: 233-240.

Lkhagvadorj, D., Hauck, M., Dulamsuren, Ch. \& Tsogtbaatar, J. 2013. Pastoral nomadism in the forest-steppe of the Mongolian Altai under a changing economy and a warming climate. Journal of Arid Environments 88: 82-89. http: / / dx.doi. org/10.1016/j.jaridenv.2012.07.019

Litterski, B. 2006. Foliose and fruticose lichens of Kyrgyzstan. Herzogia 19: 177-190. 
Mayrhofer, H. \& Sheard, J.W. 2007. Rinodina archaea (Physciaceae, lichenized Ascomycetes) and related species. Bibliotheca Lichenologica 96: 229-246.

Moniri, M. H. \& Kukwa, M. 2009. Additions to the lichen biota of Iran. Mycotaxon 110: 155-161. http: / /dx.doi.org/ 10.5248/110.155

Orange, A. James P.W. \& White F.J. 2001. Microchemical methods for the identification of lichens. British Lichen Society, London.

Palka, K. \& Śliwa, L. 2004. Lichen species new to Mongolia. Polish Botanical Journal 49: 35-43.

Palka, K. \& Śliwa, L. 2006. Lichens of Oron Dash protected area in the Lake Khubsugul National Park (Mongolia). Part 1: corticolous and lignicolous species. Nova Hedwigia 82: 51-68. http: / / dx.doi. org/10.1127/0029-5035/2006/0082-0051

Ropin, K. \& Mayrhofer, H. 1993. Zur Kenntnis corticoler Arten der Gattung Rinodina (lichenisierte Ascomyceten) in den Ostalpen und angrenzenden Gebieten. Herzogia 9: 779-835.

Schubert, R. \& Klement, O. 1971. Beitrag zur Flechtenflora der Mongolischen Volksrepublik. Feddes Repertorium 82: 187-262. http://dx.doi. org/10.1002/fedr.19710820302

Sedelnikova, N. V. 1990. Lishayniki Altaia i Kuznetskogo nagoriya [Lichens of the Altai and the Kuznetskogo mountain]. Siberian Branch of Academy of Sciences of USSR, Central Siberian Botanical Garden, Novosibirsk (in Russian).

Sheard, J. W. 2010. The lichen genus Rinodina (Ach.) Gray (Lecanoromycetidae, Physciaceae) in North America, north of Mexico. NRC Research Press, Ottawa.
Šoun, J., Vondrák, J., Søchting, U., Hrouzek, P., Khodosovtsev, A. \& Arup, U. 2011. Taxonomy and phylogeny of the Caloplaca cerina group in Europe. Lichenologist 43: 113-145. http://dx.doi. org/ 10.1017/S0024282910000721

Urbanavichus, G. P. 2010. A checklist of the lichen flora of Russia. Nauka, St. Petersburg.

Urbanavichus, G. P. \& Urbanavichene, I. N. 2005. Lichens of the genus Physconia (Physciaceae) in Russia: taxonomical review and distribution. Botanicheskii Zhurnal 90: 196-215.

van den Boom, P. P. G. \& Brand, A. M. 2008. Some new Lecanora species from western and central Europe, belonging to the $L$. saligna group, with notes on related species. Lichenologist 40: 465-497. http:/ /dx.doi.org/10.1017/S0024282908007299

Verseghy, K. 1962. Die Gattung Ochrolechia. Nova Hedwigia Beiheft 1: 1-146.

Wagner, V. \& Spribille, T. 2005. Preliminary checklist of the lichens of Kazakhstan. 1 July 2005. http:/ / www.geobotanik.org/spribille/documente/kazakhstan_list1jul2005.pdf.

Wei, J.C. 1991. An enumeration of lichens in China. International Academic Publishers, Beijing.

Wetmore, C. M. 2004. The isidiate corticolous Caloplaca species in North and Central America. Bryologist 107: 284-292. http://dx.doi. org/ 10.1639/0007-2745(2004)107[0284:TICCS I]2.0.CO;2 